DOI https://doi.org/10.36059/978-966-397-145-2/101-123

\title{
PHILOSOFY OF INCLUSIVE EDUCATION IN THE CONTEMPORARY SOCIETY
}

\section{Orlenko I. M.}

\section{INTRODUCTION}

The society these days experiences social, legal and economic crisis, and goes through in-depth transformation that change the core principles according to which it functions. At the end of the last century the world community created conditions that weakened the borers between countries and populations, these changes resulted from ubiquitous digitalization and broadening of the international community. At the same time, despite the expectations, the world became more prone to conflicts. Ethnic, religious and economic challenges have become more acute. The main goal of development of the modern society is to reach the level when the diversity is respected, the principles of solidarity and safety are defined, which would ensure protection and full integration of all social strata into the wider society. Accessibility of quality education for children with special educational needs gains bigger importance. Like in most countries in the world, the concept of inclusive education in Ukraine is used mostly in relation to people with special educational needs.

At the present time inclusion is viewed as a principle of organizing the human society at all functional levels. Inclusion is seen not only as a desirable type of behavior, but in some cases as an imperative, based on the way it is related to certain values, meanings and motivations. At the same time inclusion comes as an issue of interaction between people, that is created by development of the society.

Studies on inclusion are becoming more important as the number of children in need of social adaptation and integration into active social 
life increases. Limitations on vital activities stemming from the particularities of physical and physical development leads to social maladjustment and becomes an obstacle to mastering relevant professional skills in the future. Mastering social skills by children with special educational needs and their inclusion into the existing system of social relationships requires additional efforts. These days social initiatives in our country stipulate that transition towards inclusive education (that foresees creation of special educational environment that meets the needs and capabilities of every child regardless of his or her developmental particularities, bans any kind of discrimination and ensures even treatment of every person) must become priority in development of the national system of education ${ }^{1}$. Creating inclusive educational environment however needs to be based on values that promote inclusion. Development of inclusive education reflects the present-day social and cultural situation and contributes to higher efficiency of the educational system, improving the ways in which educational process is organized and also supports better functioning of the social system through overcoming marginalization of children with special needs and their families. "Social inclusion" was a concept born as a response to growing social inequality stemming from new labor market situation and inability of existing system of social security to meet the needs of different social groups" ${ }^{\text {.2 }}$. Co-education in the meaning of inclusion of the children with special needs into the groups with children with developmental particularities was introduced and promoted in the European educational practice by J. H. Pestalozzi (1746-1827).

1 Колупаєва А.А., Таранченко О.М., Білозерська I. О. та ін. Основи інклюзивної освіти. URL: http://education-inclusive.com/wp-content/docs/Navchalnometodychnyj-posibnyk-Osnovy-Inklyuzyvnoyi-osvity.pdf

2 Українсько-канадський проект «Інклюзивна освіта для дітей з особливими потребами в Україні»: тренінгові модулі. К., 2011. - 124 с., р. 7. 
In the present-day world education becomes one of the leading factors of development of the society as a system and also of individual social mobility. As a mobility factor it significantly increases "...chances of climbing higher on the social ladder, and in some cases becomes a condition for this to happen"3. This creates particular role of inclusive education and contributes to possibility for it to respond to changes in peoples professional needs, needs in specialists with different qualification degree, adjustment of educational capacities to needs of children with psychological and physical needs.

Everything mentioned above reflects the key role played by the educational system, one of the main public and social institutions in charge of organizing common spiritual space, preparing a person to life in multiethnic society and full self-realization of every person. Work of the educational institutions related to defining new strategies, development of the philosophy of inclusion and accepting diversity is in high social demand. There is a search of the philosophical underpinnings for education that is aimed at inclusion. Nowadays it becomes obvious that local inclusive models cannot be developed through extrapolation, or formal transfer of models of integration that proved to be successful abroad, into rigid local study conditions at the public educational institutions without studying philosophy and theory backing them. Comparison of context and domestic practices related to inclusion with the international theoretical and methodological approaches related to educational integration would contribute to adjusting domestic integrational processes, overcoming mistakes that have been made and prevent new issues in the future. Further work focused on philosophical aspect of inclusive education would contribute to this.

Philosophy embedded in inclusive education aims to support transformation of common human values into attainable goals related to

3 Печенкин В. Проблема образования в представлениях инвалидов / В. Печенкин, Д. Зайцев // СОЦИС., 2008. № 3. - С. 92-97., цит. по 2, с. 92. 
education. Defining specific goals of the daily educational activities undertaken by teachers is almost impossible without examining common goals and strategic issues related to education, taking into consideration social and public and also personality-centered dimensions.

\section{Research of the Philosophical Issues Involving Inclusion}

The idea of inclusive education was born in the United States of America as a groundbreaking conception of civil rights and antidiscrimination conception of educational policy concerning people with disabilities. It gained wide recognition upon adoption of the Disabilities Act of 1990 and also a range of other pieces of legislation in the European countries. Inclusive education and upbringing, which is a logical stage of the development of education in the world, is a process involving all highly developed countries.

Inclusive education is a relatively new phenomenon in the rest of the world and particularly in Ukraine. Integration of children with special educational needs in our country started quite recently, in 1990s. In 2001 the Ministry of Education and Science of Ukraine, the Institute of Special Pedagogics of the Academy of Pedagogical Sciences of Ukraine and the All-Ukrainian Foundation "Krok za Krokom" (Step after Step) launched a scientific and pedagogical experiment entitled "Social Adjustment and Social Integration of Children with Developmental Particularities through Education Provided at the Public Institutions". Its main goal was development and implementation of the mechanism of inclusion of children with special needs at the public institutions and their early integration into social environment that takes into consideration general and individual characteristics. Inclusive education got legal backing in 2010 with changes made to the Law on General Secondary Education that stipulated that general educational institutions could organize both special and inclusive classes for children with special needs. In October 2010 the Ministry of Education and Science of Ukraine approved the Conception on Development of 
Inclusive Education, and in August 2011 the Cabinet of Ministers of Ukraine approved the Procedures on Organization of Inclusive Education at General Public Institutions. Nowadays incisive education is being introduced in all regions of Ukraine. Undoubtedly, inclusive education as an innovative approach is faced with numerous problems, including namely professional training of teachers at public secondary schools who have to work with children with special needs, unsuitability of buildings to the needs and capabilities of such children, inadequate legal base, lack of additional funding given for inclusive institutions, academically overloaded study programs that are hard to adapt to the educational needs of children, low level of methodological support, negative attitudes towards inclusive education from parents of children without any developmental particularities. Another factor that can hold back development of this kind of education is insufficient consideration of domestic and foreign practice related to work with children with special needs in education. These days in our country we see a paradoxical situation that is however very common to transition period: whereas the acting legislation declares rights of the children with special needs to development, education and social integration, at the same time it provides no clarity and no mechanisms regarding attainment thereof ${ }^{4}$.

In the first half of the XIX century, utilizing new approach in educating children in France, Austria and Germany revealed its advantages, namely, a) more children attend educational institutions, b) the family is actively involved in educating children with special needs, c) the method of educating children from the mentioned category is getting expanded and improved, d) saving money through decrease of the number of teachers and the educational institutions. When these advantages were realized, in Germany in 1832-1834 special courses on

4 Основи корекційної педагогіки : навчально-методичний посібник / С. П. Миронова, О. В. Гаврилов, М. П. Матвєєва ; [за заг. ред. С. П. Миронової]. Кам'янець-Подільський : Кам'янець- Подільський національнийуніверситет імені Івана Огієнка, 2010. - 264 с. 
work with children with special needs were open for the teachers from the public schools; these involved more than one hundred teachers. In France, the practices in educating such children at the public schools of A. Blanche, G. Valade-Gabel contributed to development of inclusive programs. In 1958 a monograph by A. Blanche was published, entitled A Teacher`s Guide: On the Educating Deaf-Mute Children at the Public Schools. A Short Summary of the Conference that Took Place in 1858 Upon a Request from the Ministry of Interior. The methodological value of this work was prompted by the samples of the lessons that it contained, the suggested methods that involved use of facial expressions, gestures, dactyl alphabet for deaf children in general public educational intuitions ${ }^{5}$. Later, in the end of the XIX century universal education and the educational levels are introduced in the majority of European countries. Both the number of schools and the number of children at schools increase (from 30-80 persons). Lack of individual approach that is needed by children with special needs makes it not possible to continue their education among other children. As a result special education becomes separated from general, which is the most explicitly seen in the Scandinavian countries. The processes of integration are revitalized as the social-democratic and liberal-democratic reforms that took place in many countries in the XXth century. Important international legal acts that protect rights of the persons with special needs are adopted. In the 60s and 70s in Sweden and later in the majority of developed countries the boarding schools and psychiatric clinics for people with developmental delays are closed. For the international community a World Conference on Special Needs Education held under the guidance of UNESCO at Salamanca, Spain. After this event the term inclusion was introduced into the educational practice and inclusive

5 Колупаєва А.А., Таранченко О.М., Білозерська I. О. та ін. Основи інклюзивної освіти. URL:http://education-inclusive.com/wp-content/docs/Navchalnometodychnyj-posibnyk-Osnovy-Inklyuzyvnoyi-osvity.pdf 
education was recognized as a principle. Nowadays it can be said with confidence that inclusive education foresees not only active inclusion of children with particularities of psychological and physical development to the public educational institutions, but also building the system and processes of general public education aiming to meet educational needs of all categories of children. Analysis of the international practice related to educating children with special needs in other countries reveals that in the majority of them, although with insignificant differences, the special education underwent the process of reform. In many countries, namely, in Finland, Belgium, France, Ireland, Spain and Sweden children who need special education can receive it both at the special educational institutions and also at public schools ${ }^{6}$. Keeping both general and special education is possible under conditions of creating inclusive schools in Ukraine. Namely, this is suggested in the National Strategy on Development of Education in Ukraine Until 2021, which namely sets the following tasks for educating children with special needs: improving the network of special educational institutions, creating new models and forms for organizing special education, opening of specialized preschool groups working with children with similar developmental particularities that live in rural areas, expansion of inclusive and integrated education in preschool, general schools and extracurricular educational institutions for children and youth that require special approach based on particularities of their physical or mental development ${ }^{7}$.

Expansion of the educational space is a logical stage of development of the society. Accessibility of education, both physical

6 Кугуєнко Н.Ф. Світовий досвід інтегрування дітей 3 особливими освітніми потребами в загальноосвітні навчальні заклади. Джерело педагогічних інновацій - управління освіти. URL: kominternovskiy-ruo.edu.kh.ua/Files/.../ Джерело_Силина_2013.doc..

7 Ашиток Н. Проблеми інклюзивної освіти в Україні., с. 4-11. Людознавчі студії. Серія: «Педагогіка». Випуск 1/33, 2015. URL: http://dspu.edu.ua/pedagogics/? page_id=174 
and institutional, has a key role in the process of inclusion of the population into the educational practice. In the present-day context enrolment of children with special needs into the general schools and colleges thanks to creation of special conditions therein is particularly important.

Different branches of philosophical study allow us to examine the ideas embedded in inclusive education. Acceptance of heterogeneity, tolerance, humanity were in the focus of scholars belonging to many schools of thought throughout the history of philosophy. The first traces of this kind of research can be found in the works by Aristotle ${ }^{8}$, Heraclitus ${ }^{9}$; later these are elaborated in the works of modern researchers working in the domain of social philosophy, anthropology and journalism, both Western European and domestic.

Different authors present their definition of inclusion: it is viewed as the aspiration towards a golden mean (Aristotle); alleviation of suffering (Thomas Aquinsky), compassion (J. J. Russeau, A. Schopenhauer $)^{10}{ }^{11}$; obligation of all human beings (E. Kant $)^{12}$; ensuing the reasonable balance $(\mathrm{J} . \mathrm{W} \text {. Goethe })^{13}$; internal controller of my attitude towards the other (J. P. Sartre) ${ }^{14}$.

For philosophy, as for one of the forms of the public consciousness, development of the philosophical background of inclusive education as a new social and cultural reality, and elaboration of methodological basis for studying the rules of introduction and

${ }^{8}$ Аристотель. Поэтика. - Л., 1927. - 120 с; Этика Аристотеля. - СПб., 1908.

${ }^{9}$ Гераклит. Материалисты Древней Греции. Собрание сочинений Гераклита, Демокрита и Эпикура. - М., 1955.

10 Руссо Ж.-Ж. Об общественном договоре или Принципы политического права. - М., 1938.

${ }^{11}$ Шопенгауэр А. Свобода воли и нравственность. - М., 1992

12 Кант И. Сочинения в 6-ти т. - М., 1963-1966.

${ }^{13}$ Гете И.В. Страдания Юного Вертера. Соч. в 2-х т., Т. 1. - М. 1985.

${ }^{14}$ Сартр Ж. П. Первичные отношения к другому: любовь, язык, мазохизм / Проблема человека в западной философии. - М., 1988.; Сартр Ж. П. Экзистенциализм - это гуманизм // Сумерки богов. - М., 1990. 
development of the inclusive processes. This is possible in the following philosophical and methodological aspects as historical and philosophical, ontological, gnoseological, axiological, philosophical and anthropological, social and philosophical.

Foreign research and conceptions of inclusive education are based on the philosophical ideas of existentialism, pragmatism, postmodernism, phenomenology that gain recognition as part of an interactive approach in the theory and practice of specific fields of study, such as psychology, pedagogics and social studies. The philosophical schools mentioned above gave start to personalist, social and phenomenological and social ecological branches, which are theoretical and methodological bases of inclusive education in foreign pedagogics. Thus, existentialist philosophy suggested a new view on people with special needs, on their individual and social functioning, coming up with a central idea - existence, or the core part of the human self that allows every person to act as a unique and free person that chooses and builds his or her own life, bears responsibility for his or her actions directed towards self or the world around ${ }^{15}$.

Pedagogical conception of the social and phenomenological approach (also in the structure of an interactive approach) is presented in the works by C. Mollenhauer, T. Thomas, E. Hofmann. Phenomenological approach in the pedagogical work means understanding personality of a child, his or her emotional experience that are shaped by specific social, spatial linguistic environment. For a child with special needs inclusive educational environment appears the best in terms of development opportunities ${ }^{16}$.

\footnotetext{
${ }^{15}$ Теоретические и методологические основы образовательной интеграции Инклюзивное образование: методология, практика, технологии. URL: http://psyjournals.ru/inclusive_edu/issue/43976_full.shtml

16 Теоретические и методологические основы образовательной интеграции Инклюзивное образование: методология, практика, технологии URL: http://psyjournals.ru/inclusive_edu/issue/43976_full.shtml
} 
Inclusive education in pedagogics is viewed as a process of development of the general education, which means education that can be accessed by anyone because it is tailored in a way that meets the needs of every child, and therefore children with special needs also have the opportunity to benefit from it. It rests upon elimination of any form of discrimination and equal treatment of all people. Inclusive education as a pedagogical system that incorporates special and general education was introduced by L. S. Vyhotsky, who pioneered in explaining the need in this approach in the 1930s. His thoughts on the connection between being socially active, on the social environment and individual development of a person became a methodological foundation of social and educational integration of children who have developmental issues ${ }^{17}$.

Thus, philosophical and pedagogical anthropology allows the reearchers to examine the anthropological aspects of the issue of education and development of a person with special needs in the system of inclusive education based on the idea that a person whose capabilities are limited, even more than other people who do not have any limitations, needs education that makes possible selfdevelopment and self-realization that ensure the unity of mental, physical and spiritual wellbeing. This can be ensured only through constant communication between a person and his or her social and cultural environment throughout life and activities in a specific historic period.

Axiological ideas of some of the modern philosophical schools help to analyze the issues related to perception of the value of inclusive education and a person with special needs that is involved in this education; the outcomes can be used for solving ontological issues such

17 Жукова Н.Е., Палхаева Е.Н. УНИВЕРСИТЕТСКАЯ МОДЕЛЬ ИНКЛЮЗИВНОГО ОБРАЗОВАНИЯ: ОТ ИДЕИ К ПРАКТИКЕ. СовременНЫе проблемы науки и образования., 2016. № 3. URL: http:// www.science-education.ru/ru/article/view?id=24748 
as the quality of life of a person with special needs who can and cannot access inclusive education. The way these issues are addressed defines the particularities of social and philosophical understanding of life and, first of all, of education, socialization and survival in the modern world of a person whose capabilities are limited.

Research into philosophical aspects of inclusion cannot be complete without considering the aspect of ethics as norms and rules of human behavior, responsibilities of people towards each other in common study environment, the issue of creating the concept of inclusive study environment under the influence of humanist ideas. In the recent years researchers turn their attention to pedagogical deontology - obligation, moral requirements and norms as the form of manifestation of social need in the professional activities of teachers, which are specific for morale, and also is relevant for teachers working in inclusive environment (M. N. Nazarova, I. A. Phylatova, I. M. Yakovleva).

Specific feature of philosophy as a field of study is its ability to add details to the worldview. Philosophy allows the person to realize the world around, his or her place in this world, the attitude to this world and the self, the intentions and the ways those can be brought to life. Worldview is both a knowledge (about the world, a person, etc), and the assessment of the world and the self by a person. Thanks to all these characteristics philosophy plays a key role in inclusive education.

\section{Philosophy of Values Related to Inclusion in the Present-Day Ukrainian Educational Space}

These days the law on inclusive education is being actively implemented in Ukraine. Inclusive education is being introduced at the universities, colleges, schools and kindergartens. Our country adopted the International Classification of Functioning, Disability and Health, or ICF, and in 2018 transition from the medical model of treatment of 
people with disabilities was replaced by biopsychosocial. Undoubtedly the level of tolerance towards diversity at the educational institutions is increasing, however differences are still given a lot of attention. Evaluation of heterogeneity must be viewed as pointing at differences regarding one or several features. Didactic assessment views diversity as a didactic challenge. Critical view on diversity is focused on heterogeneity as a consequence of social inequality. Unfortunately the society does not always treat children with special needs with tolerance. Commonly the parents of children without physical or mental developmental issues oppose joint inclusive studies. The reason leading to this social situation is also insufficient academic level of teachers, lack of precise information about children with special needs and also the marginal status of this social group. Social environment influences the way a child with special educational needs sees the world, it changes his or her attitudes and allows the feeling of full membership at the society, successful integration therein and hence successful socialization. Inclusive environment provides many opportunities to create effective conditions for successful realization of rights of children with special educational needs only if these children are seen as equals in the society where inclusive values have due recognition. Philosophy of education views inclusion from another angle: children with special educational needs are treated as one of the many minorities, not as those who have physical imitations, and also captures all dimensions of heterogeneity (capabilities, gender, ethnic background, mother tongue, belonging to a particular social stratum, religion, physical condition etc.); it underscores the importance of observance of civil rights and combatting marginalization. It also presents the concept of the world as inclusive society. The main principle of inclusive education is in acceptance of children with special educational needs to general public schools that takes place regardless of social background, the levels of physical, emotional and intellectual development and creating special conditions that meets the 
needs of these children. Inclusive education is a recognition of the value of differences that are common to people and their ability to learn in the environment that is organized in a way that best matches their needs. It is a flexible system that takes into consideration not only needs of people with developmental issues but also different ethnic and social groups. It is the educational system that changes for such people, not the people. Dealing with diversity means dealing with differences, avoiding to create the situation of injustice and discrimination. Special needs are related to life situations, not to specific children. Positive attitude, acceptance and cooperation with children with special educational needs are the conditions under which the dreams of such children come true, and hence also the conditions that allow them socialize and enter the educational space. Inclusive education unites theories of education, upbringing, education and development that keep away the labels and categories; it puts forward the rights of vulnerable and marginalized children, porting their participation in all areas of life and aiming at structural changes at the educational institutions in order to enable every child get quality education. Increase of participation means minimizing the impact of a developmental particularity through changes in the environment. Acceptance of children with special needs is a process that goes through different phases and has its own particularities. When the parents face issues accepting their child, it impacts his or her quality of life and further social integration. Erica Shuhardt, a social scientist and an author of a work entitled Social Integration of People with Disabilities describes a spiral-like model in the process of accepting a child with special needs. This model allows us to understand the ambivalent situation between uncertainty and certainty passed by the parents of the particular child after birth, and the difficulties faced by parents as they are trying to accept their child. Acceptance can give a new chance to a happy parenthood. The closest people, a family`s social contacts, interaction with the society give an opportunity not 
only for a child`s integration into social environment, but also to social inclusion $^{18}$.

The best precondition to normal development of a child and his or her socialization is best possible when most of the attention is paid to strengths, not weaknesses. It is hard to dispute that children with special needs have atypical development that is different for different children. However this should not lead to social isolation of special children, which is exactly what is happening nowadays. Disruption of social networks, decreased social participation and solidarity were viewed by H. Silver as "manifestations of social rejection" 19 . Inadequate level of individual social integration does not allow a special child to build significant social connections with others and take part in the social activities, which limits future life opportunities. Unavailability of accessible inclusive educational space deprives children with special needs of the chances to be competitive at the job market, get additional education and profession that is in high demand, and also makes it impossible for them to live a normal active life.

The core ideas embedded in inclusive education are prohibition of any forms of discrimination and equal attitude to all people but also special conditions for children who have special educational needs. Approaches to teaching and learning that are developed within inclusive education ensure better match to different needs of people related to education. In case the system of education becomes more effective thanks to using new approaches, it will be beneficial not only for those who have special needs, but also for wider society. As part of development of inclusion in Ukraine the system focusing on providing

18 Хендріка Граф-де Реутер Прийняття дітей з особливостями розвитку та школьна інклюзія: швейцарськи реалії. Доклад. - Друга всеукраїнська конференція по синдрому Дауна. 10-11 листопада 2017. Київ., С. 39, p. 11.

19 Silver H. Social Exclusion and Social Solidarity: Three Paradigms. URL: http://www.socialinclusion.org.np/userfiles/file/SocialExclusion_and_Solidarity_by_Hill ary_SILVER.pdf 
psychological assistance to children with special educational needs has been created. It includes creation of inclusive and resource centers and regional centers on support of inclusive education. As to the phenomenon of incisive education, the methodology to be chosen depends on the goals, tasks and specific activities to be undertaken as part of it. Thus, based on system-structural and functional versions of the systemic approach in analysis of the process of implementation of an educational integration in our country it is possible to say that from the two models of organizing and managing that are usually used for this process (the Co-Existence and also the Merger models) Ukraine, as well as the USA chose the second option, merging in which a fundamental principle of educational integration, namely, freedom to choose the place of studying, is violated. Most of the European countries (and also Japan) chose a different model, Co-Existence, taking into consideration the key ideas of the educational integration ${ }^{20}$. This last model allows children with particularities of physical and psychological development to choose the institution that would best contribute to their development.

Unpreparedness of the educational institutions to training specialists that would be able to work in inclusive schools. Change of the structure of special education and increase of the number of special children of preschool and school age require upgrade and revisal of the quality of the training provided to future teachers, and better skills of professors is an essential element in the process.

While solving specific tasks at the educational facility it is necessary to take into consideration several factors that have a strong connection, which are revisal of the content and the methods of higher educational institutions that would allow to train the teachers for inclusive schools and consider specificity of the educational process

20 Обзор методов и методик системного анализа применительно к управлению качеством предприятия. URL: https://cyberleninka.ru/article/n/obzormetodov-i-metodik-sistemnogo-analiza-primenitelno-k-upravleniyu-kachestvom-pre dpriyatiya 
(aimed at understanding and considering individual needs of special students based on their age, character, degree of the issue they have, personal qualities; the need in keeping high quality of teaching which prompts search for an "individual" style of teaching that should involve high level of professionalism and individual approach to every student, use of individual forms of teaching that allow from the very start to involve students in practical activities under inclusive education; networking between the teachers at the higher educational institutions and the inclusive educational facilities aimed to clarify the content of academic and practical curriculums and also to support scientific research.

Inclusion envisions that, thanks to it, all members of the society will get more opportunities, not only children with special needs. It creates conditions under which every person can feel accepted and see his or her capabilities and needs taken into consideration and realized. Integrative and inclusive approach from the philosophical point of view suggests that social value of a specific person does not depend on his particularities and limitations; it is defined by whether he or she is included into the social practices. Success of social inclusion of children with special educational needs depends on whether social conditions for meeting basic universal human needs are created.

Philosophy of inclusive education, as well as the whole process of social inclusion supports diversity not only to promote interests of particular groups, as integration, but aiming at development of the democratic society where rights and freedoms are respected, which contributes to better quality of life of all citizens. Modern scientists describe the following basic social categories of inclusive processes:

1. Value of a person does not depend on his or her capabilities and achievements.

2. Every person is capable of feeling and thinking.

3. Every person has the right to communication and to being listened to. 
4. All people have need in each other.

5. Education can only be real if it involves real relationships.

6. All people need support and friendship with people of the same age.

7. For all those who are learning the progress lies in what they are able to do, not in the things they cannot.

8. Diversity strengthens all sides of the life of a person ${ }^{21}$.

Social ideas embedded in the phenomenon of inclusion reflect basic universal human values based on humanity and equal rights. Inclusion suggests that all people are individuals with different needs, therefore priority is give to support of the children with special educational needs so that they can realize their rights and be members of respective groups and society as a whole.

Inclusion realizes the principle of ensuring equal access to certain social services or benefits, creating necessary conditions for achieving good social status for all people without any exclusions, regardless of their capabilities, achievements, cultural and linguistic background, psychological and physical capabilities. On the one had, discrimination is prevented, the idea of equal rights is realized. On the other hand, special conditions have to be created without any barriers so that all population has access to social resources for children with special needs in education.

Therefore, the idea of inclusion stems not from pity or charity, not also from mercy of the "healthy society", but from the idea of equal rights and freedoms for all citizens without exceptions.

Inclusion is aimed at increasing the degree of participation of all people in the social processes.

21 Матвеев М. В., Ковтун Т. Ю. Адаптация детей с ограниченными возможностями как социокультурная проблема // Научно-методический электронный журнал «Концепт», 2017. Т. 26. С. 223-227. URL: http:// e-koncept.ru/2017/770757.htm. 
The difference that exists between inclusion and integration is that in the former case all people have interest in its development, not only people with special needs. All of them actively participate in reaching an expected outcome of inclusion, because all people, regardless of their particularities not only aim at the same social goals in the inclusive society but also achieve them, although possibly using different ways (these goals are good social status, self-realization, affections).

Philosophy of inclusive education contains potential that has particular value for education: problematic nature, possibility of several types of response, reflexive and tolerant attitude towards the cognitive instruments, requirement of its being logical and coherent, involving cognitive, ethical and aesthetic capabilities of the consciousness. All this makes its instruments unique and irreplaceable in order to develop skills of non-rigid, flexible context-specific and at the same time evidencesupported thinking. Universality of philosophical categories allows to overcome fragmented character of the academic knowledge provided at schools, make it coherent and well-structured for the child of school age to be able to process it. For people who just start their independent and professional life disciplinary framework common to philosophy allows to have a discussion about very diverse topics and thus define their essential life positions through reflecting upon their preferences, as the systems of values are very diverse among different people. Development and formation of social capabilities of a child with special educational needs, also the way these support co-existence of the community support further shaping of the economy of the state and its proper functioning.

Philosophical knowledge gives chance to look for these guidance in the universalist framework, which is important for the society that is far from peaceful. It stipulates that all people are born free and equal in possession of their rights and dignity and suggests a value nature of the way an individual treats him- or herself and treatment of others as values. Among the basic philosophical categories related to inclusive education are acceptance of diversity, respect, self-realization, universal 
human values (communication, affections, friendship, experiences as values etc.).

For this reason philosophy today is viewed as a potential tool for educating, namely, of the tolerant attitude and behavior. Recognition of all people as having equal value for the society, regardless of their capabilities is a defining philosophical idea behind inclusion.

\section{CONCLUSIONS}

These days inclusion is a strategy of not only educational but also social policy that envisions creation of conditions for multidimensional inclusion of people whose human potential has not been fully utilized into economic, social, political and cultural processes.

Inclusion and inclusive education are the process of development of education that foresees access to education for everybody through adjusting to the needs of all students, which opens the possibilities for people with special needs. The strategy of creating human and social capital in this important social sector is deeply related to equal access to higher education for all social groups, which means respect to diversity and paying due attention to educational needs and capabilities of students.

All people on the planet are different: they have their own dreams, different feelings. Children with special educational needs also have dreams that bring a lot of emotions, with the most important ones being the same with everyone else, live a happy, full life. Every human being is unique and valuable just because he or she was born, just because there is no second person on Earth that would be exactly the same. From the philosophical point of view social effect of inclusive education is viewed as a benefit for the society thanks to ability of children with special educational needs to feel themselves fully integrated (quality social adjustment).

The meaning given by philosophy to the education is the possibility to reflect on the special points in culture that are embedded in 
the educational process. Philosophy of education here becomes a philosophy of life of a person who aims to participate in the culture and gets opportunity to fulfill his or her potential. Philosophy is a special field of knowledge that provides a person with a framework for axiological reflecting over a certain experience and defines the frame of reference with regard to tolerant and intolerant behavior.

Education plays a crucial role in development and maintaining the system of values upon which the society is based - a 'system that is open, comprises a lot of components, culturally rich and supporting establishment of true patriotism and civil awareness.' Educational space comprises 'horizontal and vertical levels of management of the multifunctional and complex educational system at the federal, regional and municipal levels.' Educational space can have integrity only when the institutions making it up come together to solve pressing or prospective issues and the unity is ensured by the state of economy and the moral texture within the state. Philosophical and educational analysis of the meaning of the scope and substance of the entities participating in the educational process, interrelation of their values allows to fill the formal educational models with specific content that reflects in-depth issues embedded in the educational process.

The aim of the philosophy of education is to support conceptual aspect of the process of transformation of inclusion as a universal human value into values and aims that are being incorporated into education. Education that is aiming at inclusion has a potential to form new meanings, including philosophical and didactic meaning. It brings up and reflects the particularities of one`s perception of the world and one`s place in it.

Philosophical approach towards individuals creates new meanings, sets new milestones in exploring people. Therefore it can be (and is growing as) a key approach towards personality in a pedagogical sense. Revival of inclusion in the educational process foresees that the accent is made on the principle of humanity between the parties that are involved in it. 


\section{SUMMARY}

The article is dedicated to analysis of the philosophical conception of inclusive education as a principle that supports organizing human society at all levels. It points at the priority in development of the national system of education, inclusive system of education that meets the needs and capabilities of every child regardless of particularities of his or her physical and emotional development. Philosophy embedded in the inclusive education allows to supply conceptual tools to support the process of universal human values into values and goals that can be attained specifically in the educational domain. It has been established that broadening of the educational space is a logical stage of the development of the society.

Accessibility of education, both in physical and also in the institutional sense plays the key role in the processes of including population into educational practice. Philosophy of inclusive education, as well as the whole process of social inclusion supports diversity not only to promote interests of particular groups, as integration, but aiming at development of the democratic society where rights and freedoms are respected, which contributes to better quality of life of all citizens. Among the basic philosophical categories related to inclusive education are acceptance of diversity, respect, self-realization, universal human values (communication, affections, friendship, experiences as values etc.).

The meaning given by philosophy to the education is the possibility to reflect on the special points in culture that are embedded in the educational process. Philosophy of education here becomes a philosophy of life of a person who aims to participate in the culture and gets opportunity to fulfill his or her potential.

\section{REFERENCES}

1. Колупаєва А. А., Таранченко О. М., Білозерська I. О. та ін. Основи інклюзивної освіти. URL: http://education-inclusive.com/wp- 
content/docs/Navchalno-metodychnyj-posibnyk-Osnovy-Inklyuzyvnoyiosvity.pdf

2. Печенкин В. Проблема образования в представлениях инвалидов . СОЦИС, 2008, № 3. - С. 92-97.

3. Українсько-канадський проект «Інклюзивна освіта для дітей $з$ особливими потребами в Україні»: тренінгові модулі. К., 2011. -124 c.

4. Основи корекційної педагогіки: навчально-методичний посібник. С. П. Миронова, О. В. Гаврилов, М. П. Матвєєва [за заг. ред. С. П. Миронової]. Кам'янець-Подільський : Кам'янець-Подільський національний університет імені Івана Огієнка, 2010. - 264 с.

5. Кугуєнко Н. Ф. Світовий досвід інтегрування дітей 3 особливими освітніми потребами в загальноосвітні навчальні заклади. Джерело педагогічних інновацій - управління освіти. URL: kominternovskiy-ruo.edu.kh.ua/Files/.../Джерело_Силина_2013.doc.

6. Ашиток Н. Проблеми інклюзивної освіти в Україні. Людинознавчі студії. Серія «Педагогіка», с 4-11. Випуск 1/33, 2015. URL: http://dspu.edu.ua/pedagogics/?page_id=174

7. Аристотель. Поэтика. Л., 1927, 120 с; Этика Аристотеля. СПб., 1908.

8. Гераклит. Материалисты Древней Греции. Собрание сочинений Гераклита, Демокрита и Эпикура. М., 1955.)

9. Руссо Ж.-Ж. Об общественном договоре или Принципы политического права. М., 1938.

10.Шопенгауэр А. Свобода воли и нравственность. М., 1992.

11.Кант И. Сочинения в 6-ти т. М., 1963-1966.

12.Гете И. В. Страдания Юного Вертера. Соч. в 2-х т., Т. 1. M. 1985.

13.Сартр Ж. П. Первичные отношения к другому: любовь, язык, мазохизм. Проблема человека в западной философии. М., 1988; Сартр Ж. П. Экзистенциализм - это гуманизм. Сумерки богов. М., 1990. 
14. Теоретические и методологические основы образовательной интеграции. Инклюзивное образование: методология, практика, технологии URL: http://psyjournals.ru/inclusive_edu/issue/43976_full.shtml

15.Жукова Н. Е., Палхаева Е. Н. Университетская модель инклюзивного образования: от идеи к практике. Современные проблемы науки и образования, 2016. № 3; URL: http:// www.science-education.ru/ru/article/view?id=24748

16.Хендріка Граф-де Реутер Прийняття дітей 3 особливостями розвитку та школьна інклюзія: швейцарськи реалії. Доклад. Друга всеукраїнська конференція по синдрому Дауна. 10-11 листопада 2017. Київ, С. 39.

17.Silver H. Social Exclusion and Social Solidarity: Three Paradigms. URL: http://www.socialinclusion.org.np/userfiles/file/Social Exclusion_and_Solidarity_by_Hillary_SILVER.pdf

18.Обзор методов и методик системного анализа применительно к управлению качеством предприятия. URL: https://cyberleninka.ru/article/n/obzor-metodov-i-metodik-sistemnogoanaliza-primenitelno-k-upravleniyu-kachestvom-predpriyatiya

19. Матвеев М. В., Ковтун Т. Ю. Адаптация детей с ограниченными возможностями как социокультурная проблема. Научно-методический электронный журнал «Концепт», 2017. Т. 26. C. 223-227. URL: http://e-koncept.ru/2017/770757.htm.

\section{Information about the author:} Orlenko I. M.,

PhD Candidate, Department of Philosophy, Social Sciences and Management of Social and Cultural Activities,

State institution «South-Ukrainian National Pedagogical University named after K. D. Ushynsky» 26, Staroportofrankivska str., Odesa, 65020, Ukraine 